Application of the picture frame effect to the hard-copy images (2nd report)

\title{
福島県泉崎村立病院 放射線部
}

○辺見 秀一

Syuichi Henmi

【目的】第51回総会 (1995:名古屋)においてハードコピー像の読影診断を想定し、白枠・黒枠での見え方の 相違を比較したところ、同一濃度であっても枠の違いによって白っぽく感じたり黒っぽく感じたりする“枠の 効果” と呼ばれる視覚特性が生じているので考慮すべきであると報告した。今回は、頭部C T画像をサンプル にパソコン (Macintosh) と画像処理ソフト (Photoshop LE-J) を利用して、濃度の見え方に影響を及ぼして いると推察される枠を作成し、これらを実際に比較検討した。

【方法】(1)白枠で囲んだ小脳レベルと側脳室上レベル（頭頂部）の2種類 の頭部C T 画像をスキャナを利用してパソコンに入力した。(2)頭蓋骨及び 背景をそれぞれ 1 つ枠と考え、オリジナルの画像（A）に対して3つの 画像 $(\mathrm{B} \cdot \mathrm{C} \cdot \mathrm{D})$ を画像処理ソフト (Photoshop LE-J) を使用してパソコ ン上で作成し（Table.1）、各々1枚ずつインクジェットプリンタで印刷 した。(3)医師 4 名・放射線技師 3 名の計 7 名で 2 個ずつ任意の順にピック アップして比較観察し、さらにその結果に対して危険率 $5 \%$ ○一標本符号 検定法による統計学的検討を加えた。

\begin{tabular}{ccc}
\hline & 頭蓋骨 & 背景 \\
\hline A & 白 & 黒 \\
B & 黒 & 黒 \\
C & 白 & 白 \\
D & 黒 & 白 \\
\hline
\end{tabular}

Table. 1

【結果】6通り比較した結果、小脑しベルでは A B 間（Aが Bよりも白っぽく）とAD間（AがDよりも白っ ぽく）、側脳室上レベルでは B C 間（BがCよりも白っぽく）に統計的な有意差が認められた。両者間では統 計的に有意な差が認められた組み合わせが異なったことは興味深い。なお、その他の組み合わせに関してはこ の視覚実験では有意差なしとなった。

【考察】 (O) B B 間：(1)小脳レベル [Fig. 1，Fig. 2]；頭蓋骨を細い白枠と判断し、その白に同化するためAの 方が白っぽく見えているものと思われる。(2)側脳室上レベル；このレベルでは同じ A B 間においても統計的な 有意差は認められない。これは小脑レベルに比べて被写体の大きさが小さくなっているので、相対して背景の 黒の幅が太くなりその影響を受けているため、Aにおける頭蓋骨が細い白枠と判断されにくく白っぽく見えて こないのであろう。@A D 間：小脳レベル；頭蓋骨に関して考えてみると、Aでは頭蓋骨の白を細い白枠と判 断し同化になり白っぽく、Dでは頭蓋骨の黒を細い黒枠と判断し同化になり黒っぽく見えているものと思われ る。さらに背景に関して考えてみると、Aでは背景の黒を太い黒染と判断し対比になり白っぽく、Dでは逆に 背景の白を太い白染と判断し対比になり黒っぽく見えているものと思われる。“頭蓋骨”之“背景”の両者が 共にAの方をより白っぽく見せるよう視覚系に働きかけているものと考えられる。

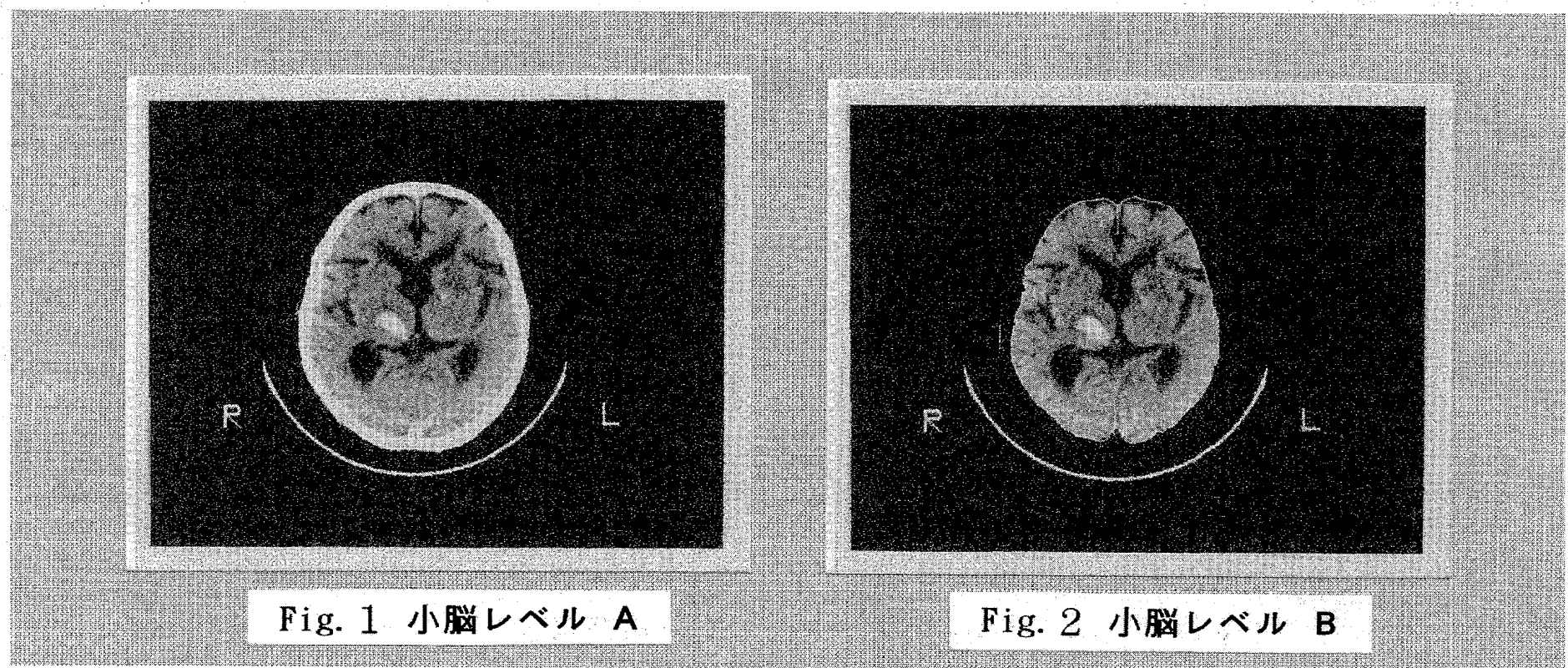

【結論】頭部 C T 画像は、脳実質・頭蓋骨（頭皮も含む）・背景の 3 者で構成されるが、小脳レベルでは頭蓋 骨の白を細い白杵とみているため脳実質が白っぽく見えているのに対し、側腷室上レべルではその傾向にない。 これは “枠の効果”が被写体の大きさ（画面に占める割合）にも依存しているためと思われる。このように仮 に脳実質の濃度が同一でもその他の 2 者がオリジナルのものと異なれば、部位により同一濃度には見えていな いことが統計学的に明らかになった。 